\title{
REPRESENTASI KESETARAAN GENDER PADA IKLAN (Tinjauan Semiotika Citra Laki-Laki dalam Keluarga pada Iklan Televisi)
}

\author{
Heppy Atma Pratiwi, Endang Wiyanti \\ Fakultas Bahasa dan Seni \\ Universitas Indraprasta PGRI \\ heppy.unindra@gmail.com, endangwiyanti76@gmail.com
}

\begin{abstract}
Abstrak
Pada penelitian ini, penulis menganalisis citra laki-laki dalam keluarga dalam konteks kesetaraan gender pada beberapa iklan di televisi yang pernah ditayangkan. Televisi menjadi salah satu media yang dapat memengaruhi kehidupan manusia melalui simbol pada iklannya. Penelitian ini menggunakan pendekatan kualitatif yang sifatnya deskriptif dan menggunakan teknik analisis semiotika model Charles Sanders Pierce. Iklan yang diteliti yaitu iklan Mama Lemon (Choky Sitohang), Supermie Ayam Bawang Jamur Yummy, Rapika Pelicin Pakaian, Sharp Sayang Listrik Super Aquamagic, Hilo (Ayah dan Anak), Belvita Breakfast, Pepsodent (Ayah Adi dan Dika), Susu SGM 3 (Pohon Strawberry), Ultra Milk Ultra Passion (Diajak ke Peternakan), Oreo (Hadirkan Keceriaan Masa Kecil), Soklin Lantai (Keluarga Bahagia Keluarga Soklin Lantai), Blue Band (Ibu Tahu yang Terbaik), SOS Pembersih Lantai (Bapak dan Anak), La Fonte Pasta (Ayah Memasak). Hasilnya kegiatan rumah tangga yang dilakukan oleh laki-laki dalam iklan-iklan tersebut yaitu bermain bersama anak sebanyak $26,6 \%$, melakukan kegiatan bersama anak dan keluarga sebanyak 35,5\%, melakukan pekerjaan rumah tangga (mengepel lantai, mencuci baju, mengoperasikan mesin cuci, mengangkat baju kering yang dijemur, menyetrika, mencuci piring, memasak, menyiapkan sarapan) sebanyak $33,3 \%$, dan memijat isteri sebanyak $2,22 \%$.
\end{abstract}

Kata Kunci: kesetaraan gender, iklan, citra laki-laki

\begin{abstract}
In this study, the writer analyzed the image of men in the family in the context of gender equality in some television advertisements that had previously been shown. Television becomes one of the media that can affect human life through the symbols on its ads. This research uses qualitative approach which is descriptive and using technique of semiotic analysis model of Charles Sanders Pierce. The ads under study are the ads of Mama Lemon (Choky Sitohang), Supermie Ayam Garam Yummy, Rapika Pelicin Pakaian, Sharp Sayang Listrik Super Aquamagic, Hilo (Ayah dan anak), Belvita Breakfast, Pepsodent (Ayah Adi dan Dika), Susu SGM 3 (Pohon Strawberry), Ultra Milk Ultra Passion (Diajak ke Peternakan), Oreo (Hadirkan Keceriaan Masa Kecil), Soklin Lantai (Keluarga Bahagia Keluarga Soklin Lantai), Blue Band (Ibu Tahu yang Terbaik), SOS Pembersih Lantai (Ayah dan Anak) La Fonte Pasta (Ayah Memasak). The result of household activities conducted by men in these advertisements is playing with children as much as 26,6\%, doing activities with children and families as much as 35,5\%, doing housework (mopping floors, washing clothes, operating machinery washing, lifting dry clothes drying, ironing, washing dishes, cooking, preparing breakfast) as much as 33,3\%, and massaging the wife as much as 2,22\%.
\end{abstract}

Keywords: gender equality, advertising, image of man 


\section{PENDAHULUAN}

\section{Latar Belakang}

Keberadaan laki-laki dan perempuan merupakan dua entitas yang sering dibedakan dalam kondisi jenis kelamin (seks) dan peran yang harus dilakukan (gender). Namun, seringkali kedua konsep ini (seks dan gender) sering dimaknai sebagai ciri khas yang sama bagi seorang laki-laki atau seorang perempuan. Pemahaman yang seperti itu sering menempatkan laki-laki dan perempuan dalam situasi yang tidak seimbang atau menimbulkan ketidakadilan. Masyarakat memosisikan perempuan sebagai seorang yang lemah lembut, berperan sebagai ibu rumah tangga membesarkan anak-anaknya, menjadi pelayan yang baik kepada suami (laki-laki) mulai melayani makan, minum, dan di tempat tidur. Sebaliknya, laki-laki berperan sebagai kepala rumah tangga yang kuat, melindungi keluarga serta memiliki banyak hak istimewa dalam keluarga. Padahal, pandangan tersebut merupakan situasi yang ber-kaitan dengan apa yang disebut dengan gender.

Dalam keluarga Indonesia pada umumnya, orangtua atau lingkungan, baik secara langsung maupun tidak langsung telah menyosialisasikan peran anak laki-laki dan perempuannya secara berbeda. Anak laki-laki diminta membantu orang tua dalam hal-hal tertentu saja, bahkan seringkali diberi kebebasan untuk bermain dan tidak dibebani tanggung jawab tertentu. Anak perempuan sebaliknya, diberi tanggung jawab untuk membantu pekerjaan yang menyangkut urusan rumah (membersihkan rumah, memasak, dan mencuci). Peran gender terbentuk melalui berbagai sistem nilai termasuk nilai-nilai adat, pendidikan, agama, politik, ekonomi, dan sebagainya.

Sebagai hasil bentukan sosial, peran gender dapat berubah-ubah dalam waktu, kondisi, dan tempat yang berbeda sehingga peran laki-laki dan perempuan mungkin dapat dipertukarkan. Mengurus anak, mencari nafkah, mengerjakan pekerjaan rumah tangga (memasak, mencuci, dan lain-lain) adalah peran yang bisa dilakukan oleh laki-laki maupun perempuan, sehingga dapat bertukar tempat tanpa menyalahi kodrat.

Dengan demikian, pekerjaanpekerjaan tersebut bisa kita istilahkan sebagai peran gender. Jika peran gender dianggap sebagai sesuatu yang bisa berubah dan bisa disesuaikan dengan kondisi yang dialami seseorang, maka tidak ada alasan lagi bagi kita untuk menganggap aneh seorang suami yang pekerjaan sehari-harinya memasak dan mengasuh anak-anaknya, sementara isterinya bekerja di luar rumah. Karena di lain waktu dan kondisi, ketika sang suami memilih bekerja di luar rumah dan isterinya memilih untuk melakukan tugas-tugas rumah tangga, juga bukan hal yang dianggap aneh.

Pada penelitian ini, penulis menganalisis citra laki-laki dalam keluarga dalam konteks kesetaraan gender pada beberapa iklan di televisi yang pernah ditayangkan. Televisi menjadi salah satu media yang dapat memengaruhi kehidupan manusia melalui simbol pada iklannya. Citra media yang setiap hari disuguhkan secara terus-menerus akan menjadi pembenaran bagi penonton. Manusia dengan keragamannya memiliki cara pandang tertentu tentang sosok manusia ideal yang patut dicontohnya. Cara pandang ini tidak hanya pada pandangan fisik semata, namun berbagai hal terutama kesetaraan gender dalam keluarga seperti yang akan kami teliti.

\section{Tinjauan Pustaka}

Citra

Nilai-nilai kepercayaan yang diberikan secara individual dan merupakan pandangan atau persepsi serta terjadi- 
nya proses akumulasi dari amanah kepercayaan yang telah diberikan akan mengalami suatu proses cepat atau lambat untuk membentuk suatu opini publik yang lebih luas dan abstrak yaitu yang kita sebut sebagai citra. Dalam bahasa Inggris, citra disebut dengan istilah image, sedangkan dalam bahasa komuniksai menurut Keith Davis, citra adalah The picture in ourhead (gambar yang ada dalam kepala kita). Gambar ini dimaksudkan adalah gambar mental yang mengandung unsur positif dan negatif (Yulianita, 2005:47). Selain itu pengertian citra menurut Kasali (2005:30) adalah "kesan yang timbul karena pemahaman akan suatu kenyataan, pemahaman itu sendiri muncul karena adanya informasi".

Citra merupakan gambaran seseorang terhadap orang lain, perusahaan, produk, dan sebagainya. Hal ini dianggap penting karena citra mempengaruhi sukses atau tidaknya suatu perusahaan, atau produk yang dipasarkan digambarkan dari baik buruknya menurut masyarakat. Tanpa citra akan selalu berada dalam suasana yng tidak pasti. Citra adalah gambaran tentang realitas dan tidak harus sesuai dengan realitas. Citra adalah dunia menurut persepsi kita.

\section{Citra Laki-Laki}

Di Indonesia, nilai simbolis dari laki-laki dan perempuan dipandang sangat berbeda, dan menunjukkan bidang kehidupan yang berbeda pula. Wilayah laki-laki biasanya terletak pada bidang politik dan kekuasaan, kerja, jabatan, serta pemimpin keluarga, sedangkan pusat kehidupan perempuan berada di rumah, memasak, mendidik, membereskan urusan rumah tangga, dan mengasuh anak.

Pada penelitian, definisi laki-laki diarahkan pada konsep patriarki. Kata patriark secara harfiah memiliki arti kekuasaan ayah atau patriarch (kepala keluarga) (Bhasin, 2001:26). Hal ini mengacu pada sistem sosial. Bapak memegang kontrol (kendali) atas seluruh anggota keluarga, kepemilikan barang, sumber pendapatan, dan memegang keputusan utama. Sehubungan dengan sistem sosial ini, diyakini (dijadikan ideologi) bahwa pria lebih superior dibanding perempuan (Kurnianto, 2009:13).

Proses reproduksi juga turut andil dalam pembentukan dunia patriarki. Dunia patriarki menganggap bahwa lakilakilah yang memainkan peranan penting dalam keberlanjutan kehidupan, sehingga selayaknyalah laki-laki yang memiliki kuasa atas segala hal termasuk kehidupan perempuan. Dalam proses persetubuhan, laki-laki berperan sebagai pihak yang membuahi dan perempuan bersifat pasif menunggu untuk dibuahi. Proses tersebut melahirkan konsep bahwa yang membuahi memiliki dominasi dan kekuasaan atas yang dibuahi. Oleh karena itu saat bayi lahir dianggap milik laki-laki sebagai pihak yang membuahi, karena laki-laki merasa dialah yang menciptanya dan perempuan hanya sebagai tempat penitipan benih sperma. Oleh sebab itu, laki-laki merasa dominan, sebagai pencipta penerus generasi dan sebagai pencipta kehidupan.

Berdasarkan konsep di atas, maka alasannya dianggap jelas bahwa laki-laki merasa lebih segala-galanya dibanding perempuan. Budaya patriarki telah menyebabkan relasi laki-laki dan perempuan berlangsung dan berpusat dalam kontrol laki-laki. Hak istimewa yang dimiliki laki-laki akibat konstruksi gender telah menempatkan laki-laki untuk memiliki kekuasaan lebih tinggi daripada perempuan (Sari, 2007:198).

Peran antara laki-laki dan perempuan tidak didasarkan pada perbedaan jenis kelamin yang menempel pada diri mereka, perbedaan peran antara laki-laki dikonstruksi oleh norma, nilai, 
dan budaya yang berlaku dalam suatu masyarakat. Dalam kehidupan masyarakat yang menerapkan sistem patriarki, patriarki sering dikaitkan dengan kekuasaan yang dimiliki laki-laki. Patriarki dipahami sebagai suatu pemikiran yang menjustifikasi dominasi laki-laki dan nilai-nilai patriarki ini dipertahankan dan diwarisi oleh laki-laki dari generasi ke generasi selanjutnya.

\section{Kesetaraan Gender}

Pada dasarnya semua orang sepakat bahwa perempuan dan laki-laki berbeda. Namun, gender bukanlah jenis kelamin laki-laki dan perempuan sebagai pemberian Tuhan. Gender lebih ditekankan pada perbedaan peranan dan fungsi yang ada dan dibuat oleh masyarakat. Dalam realitas kehidupan telah terjadi perbedaan peran sosial laki-laki dan perempuan yang melahirkan perbedaan status sosial di masyarakat, dimana lakilaki lebih diunggulkan dari perempuan melalui konstruksi sosial. Perbedaan gender antara laki-laki dan perempuan ditentukan oleh sejumlah faktor yang ikut membentuk, yang kemudian disosialisasikan, diperkuat, bahkan dibentuk melalui sosial atau kultural, dilanggengkan oleh interpretasi agama dan mitos-mitos. Perbedaan jenis kelamin sering dipergunakan masyarakat untuk membentuk pembagian peran (kerja) laki-laki dan perempuan atas dasar perbedaan tersebut. Akibatnya terjadilah pembagian peran gender yaitu peran domestik dan peran publik. Peran domestik cenderung tidak menghasilkan uang, kekuasaan, dan pengaruh. Peran ini lebih banyak diserahkan kepada kaum perempuan, sedangkan peran publik yang menghasilkan uang, kekuasaan dan pengaruh diserahkan kepada kaum lakilaki. Santrock (2003: 365) mengemukakan bahwa istilah gender dan seks memiliki perbedaan dari segi dimensi. Isilah seks (jenis kelamin) mengacu pada dimensi biologis seorang laki-laki dan perempuan, sedangkan gender mengacu pada dimensi sosial-budaya seorang lakilaki dan perempuan.

Selain itu, istilah gender merujuk pada karakteristik dan ciri-ciri sosial yang diasosiasikan pada laki-laki dan perempuan. Karakteristik dan ciri yang diasosiasikan tidak hanya didasarkan pada perbedaan biologis, melainkan juga pada interpretasi sosial dan cultural tentang apa artinya menjadi laki-laki atau perempuan (Rahmawati, 2004: 19).

Gender diartikan sebagai konstruksi sosiokultural yang membedakan karakteristik maskulin dan feminim. Moore (Abdullah, 2003: 19) mengemukakan bahwa gender berbeda dari seks dan jenis kelamin laki-laki dan perempuan yang bersifat biologis. Istilah gender dikemukakan oleh para ilmuwan sosial dengan maksud untuk menjelaskan perbedaan perempuan dan laki-laki yang mempunyai sifat bawaan (ciptaan Tuhan) dan bentukan budaya (konstruksi sosial). Gender adalah perbedaan peran, fungsi, dan tanggung jawab antara laki-laki dan perempuan yang merupakan hasil konstruksi sosial dan dapat berubah sesuai dengan perkembangan zaman.

Dari beberapa penjelasan mengenai seks dan gender di atas, dapat dipahami bahwa seks merupakan pembagian jenis kelamin berdasarkan dimensi biologis dan tidak dapat diubah-ubah, sedangkan gender merupakan hasil konstruksi manusia berdasarkan dimensi sosial-kultural tentang laki-laki atau perempuan.

Ada beberapa pemikiran muncul terutama pada kelompok masyarakat yang masih menganggap bahwa sudah kodratnya perempuan untuk melakukan pekerjaan di dapur. Kita perlu ingat bahwa bukan kodratnya perempuan untuk masuk dapur, karena kegiatan memasak di dapur tidak ada kaitannya dengan ciriciri biologis yang ada pada perempuan. 
Kegiatan memasak di dapur (atau kegiatan rumah tangga lainnya) adalah suatu bentuk pilihan pekerjaan dari sekian banyak jenis pekerjaan yang bisa dilakukan oleh perempuan ataupun lakilaki (misalnya guru, dokter, pegawai negeri, sopir, pedagang, dan lainnya). Selain itu, terminologi kesetaraan gender seringkali disalahartikan dengan mengambil alih pekerjaan dan tanggung jawab laki-laki. Misalnya bekerja untuk mengangkat barang-barang yang berat, mengganti atap rumah, menjadi nelayan atau berburu di hutan dan lainnya. Kesetaraan gender bukan berarti memindahkan semua pekerjaan laki-laki ke tangan perempuan, bukan pula mengambil alih tugas dan kewajiban seorang suami oleh isterinya. Jika hal ini yang terjadi, bukan 'kesetaraan' yang tercipta melainkan penambahan beban dan penderitaan pada perempuan.

Maka, dapat disimpulkan bahwa kesetaraan atau keadilan gender adalah suatu proses dan perlakuan adil terhadap perempuan dan laki-laki. Dengan kesetaraan gender berarti tidak ada pembakuan peran, beban ganda, subordinasi, marginalisasi dan kekerasan terhadap perempuan maupun laki-laki terutama dalam peran domestik atau keluarga.

Kesetaraan gender adalah kondisi perempuan dan laki-laki menikmati status yang setara dan memiliki kondisi yang sarna untuk mewujudkan secara penuh hak-hak asasi dan potensinya bagi pembangunan di segala bidang kehidupan. Dengan kata lain, ini berarti semua manusia punya akses dan kontrol yang wajar dan adil terhadap sumber daya dan manfaatnya, agar laki-laki dan perempuan dapat berpartisipasi di dalamnya, serta memutuskan dan memperoleh manfaat dari situasi yang ada.
Iklan Televisi

Sebagai salah satu iklan above the

line, televisi merupakan media komunikasi massa yang paling efektif dan efisien sebagai media untuk meninformasikan produk dan citra suatu perusahaan. Menurut Alatas (1997:144) iklan televisi merupakan salah satu bagian dari program siaran televisi yaitu, program siaran niaga yang berisi informasi tentang suatu produk dan atau citra (image) tertentu, yang secara sengaja dan terencana diproduksi untuk memenuhi kepentingan bisnis dan tujuan usaha atau kegiatan suatu perusahaan atau instansi pemerintah.

Iklan yang ditayangkan di televisi biasanya bisa digunakan sebagai sponsor untuk suatu acara, sehingga bisa membawa keuntungan di antara kedua belah pihak. dalam bentuk partisipasi, biasanya suatu iklan hanya akan menyisipkan tayangannya pada beberapa acara saja dengan durasi yang ditentukan. Pada spot announcement biasanya iklan akan membayar sejumlah uang kepada stasiun televisi agar iklannya dapat ditanyangkan pada saat pergantian acara. Iklan yang terdapat dalam televisi tidak hanya terbatas pada iklan komersial saja, tetapi juga ada beberpa iklan yang sengaja diproduksi oleh pemerintah atau LSM demi kepentingan informasi sosial. Kita biasa menyebut iklan tersebut dengan iklan layanan masyarakat.

Jefkins (1997:109) meyebutkan beberapa kelebihan iklan televisi secara umum, yaitu:

1. Kesan realistik

2. Masyarakat lebih tanggap

3. Repetisi/pengulangan

4. Adanya pembagian area siaran (zoning) dan jaringan kerja (networking)

5. Ideal bagi para pedagang eceran

6. Terkait erat dengan media lain. 
Kesan realistik berkaitan dengan sifat televisi yang audio visual, sehingga mampu menghasilkan kombinasi warna, gerakan, dan suara yang akan terlihat hidup dan nyata. Masyarakat lebih tanggap terhadap penayangan iklan televisi ysng disiarkan dan dapat ditonton di rumah dalam suasana santai, sehingga masyarakat lebih siap untuk memberikan perhatian dan perhatian akan lebih bertambah apabila dalam iklan melibatkan orang terkenal (public figure) sebagai modelnya. Iklan televisi bisa ditayangkan ulang (repetisi) beberapa kali dalam sehari sampai dipandang efektif, sehingga memungkinkan masyarakat yang menonton dengan frekuensi yang sukup akan terpengaruh iklan yang ditayangkan. Selain itu adanya pembagian area siaran dan jaringan kerja memungkinkan seorang pengiklan dapat menggunakan satu atau kombinasi banyak stasiun televisi sekaligus untuk memuat iklannya secara serentak sehingga dapat menjangkau konsumen secara efektif. Iklan televisi dipandang ideal bagi pedagang eceran karena dapat mempermudah kelancaran penjualan produk dagangan mereka. sesuatu yang diinginkan di televisi dapat mempengaruhi konsumen untuk membeli produk yang ditawarkan dalam iklan. Selai itu pula, iklan televisi erat dengan media lainnya karena mudah dipadukan dengan iklan dari media lain. jika konsumen memerlukan informasi lebih lanjut, iklan televisi dapat dipadukan dengan iklan-iklan di majalah mingguan, khususnya majalah yang mengulas acara televisi.

Dalam penelitian ini iklan dilihat sebagai sebuah teks yang merupakan sebuah tanda (Nugroho dalam Noviani, 2002), sedangkan dalam sebuah tanda akan terkandung ideologi tertentu (Hall dalam Sobur, 2001)

Dalam perjalanan realitas, dalam kehidupan bermasyarakat pun mulai berubah. Adanya perubahan peran laki- laki dan perempuan secara demografik dalam masyarakat juga perlu diperhitungkan dalam proses kreatif pembuatan iklan (Assael, 2002). Iklan dituntut untuk mengikuti perubahan dalam masyarakat, jika tidak maka iklan tidak akan mengenai targetnya dan gagal. Masyarakat Indonesia saat ini dalam masa transisi menuju ke arah kesetaraan gender.

Untuk kepentingan, iklan dapat dibedakan menjadi tiga macam berdasarkan muatan representasi gender dalam iklan tersebut, yaitu:

1. Iklan seksis, yaitu iklan yang merepresentasikan kondisi yang seksis (bias gender).

2. Iklan semi seksis, yaitu iklan yang merepresentasikan kondisi kesetaraan gender namun juga masih memuat kondisi yang bias gender.

3. Iklan non seksis, yaitu iklan yang merepresentasikan kondisi kesetaraan gender.

Dalam penelitian ini, beberapa iklan yang akan dijadikan objek penelitian meliputi jenis iklan produk peralatan dan perlengkapan rumah tangga dan makanan, yang menggambarkan citra laki-laki dalam kesetaraan gender. Artinya peran laki-laki mampu menggantikan peran domestik dalam rumah tangga yang biasanya dilakukan atau dikerjakan oleh perempuan.

Semiotika

Semiotika dapat diandaikan sebagai metode membaca yang dikenakan pemirsa terhadap iklan yang sedang dilihatnya. Untuk mendapatkan maknanya, iklan akan dibongkar dan direkonstruksikan oleh semiotika (Kurniawan, 2001:17). Dengan demikian iklan akan menjadi milik pemirsa. Tidak diperlukan lagi untuk mencari-cari makna yang disembunyikan oleh pengiklan, tetapi akan dilihat bagaimana pemirsa memproduksi makna bagi iklan tersebut. 
Dalam hal ini yang menjadi pertanyaan bukanlah apakah pesan yang dikirim pengiklan sama dengan pesan yang diterima oleh pemirsa, tetapi bagaimana pemirsa memaknai iklan tersebut.

Semiotika sebagai suatu model dari ilmu pengetahuan sosial memahami dunia sebagai suatu sistem yang memiliki unit dasar yang disebut dengan "tanda", dengan demikian semiotika mempelajari hakikat tentang keberadaan suatu tanda. Menurut Saussure, persepsi dan pandangan kita tentang realitas dikonstruksikan oleh kata-kata dan tandatanda lain yang digunakan dalam konteks sosial, ini berarti tanda membentuk persepsi manusia, lebih dari sekadar merefleksikan realitas yang ada (Sobur, 2012). Pakar lainnya, Hamad juga mengungkapkan bahwa semiotika untuk media massa tak hanya terbatas sebagai kerangka teori saja namun sekaligus juga bisa sebagai metode analisis. Misalnya saja teori segitiga makna (triangle meaning) milik Charles S. Peirce yang terdiri atas sign (tanda), object (objek), dan interpretant (interpretan). Menurut Peirce, salah satu bentuk tanda adalah kata, sedangkan objek adalah sesuatu yang dirujuk tanda, sementara interpretan adalah tanda yang ada di dalam benak seseorang tentang objek yang dirujuk sebuah tanda (Sobur, 2012).

Model triadik Peirce sering disebut sebagai "triangle meaning semiotics" atau dikenal dengan teori segitiga makna, yang dijelaskan secara sederhana, "tanda adalah sesuatu yang dikaitkan pada seseorang untuk sesuatu dalam beberapa hal atau kapasitas. Tanda menunjuk pada pada seseorang, yakni, menciptakan dibenak orang tersebut suatu tanda yang setara, atau suatu tanda yang lebih berkembang, tanda yang diciptakannya dinamakan interpretan dari tanda pertama. Tanda itu menunjukkan sesuatu, yakni objeknya". Model triadic
Peirce dan konsep trikotominya yang terdiri atas berikut ini.

1. Representament/sign (tanda)

2. Object (sesuatu yang dirujuk)

3. Interpretant ("hasil" hubungan representamen dengan objek).

Salah satu bentuk tanda (sign) adalah kata. Sesuatu dapat disebut representamen (tanda) jika memenuhi dua syarat berikut: 1) Bisa dipersepsi, baik dengan panca indera maupun dengan pikiran/perasaan. 2) Berfungsi sebagai tanda (mewakili sesuatu yang lain). Objek adalah sesuatu yang dirujuk tanda, bisa berupa materi yang tertangkap panca indera, bisa juga bersifat mental atau imajiner sedangkan interpretan adalah tanda yang ada dalam benak seseorang tentang objek yang dirujuk sebuah tanda. Apabila ketiga elemen makna itu berinterkasi dalam benak seseorang, maka muncullah makna tentang sesuatu yang diwakili oleh tanda tersebut.

\section{METODE PENELITIAN}

Penelitian ini menggunakan pendekatan kualitatif yang sifatnya deskriptif. Penelitian ini menggunakan teknik analisis semiotika model Charles Sanders Pierce. Model Pierce membahas sign, object, dan interpretan sebagai segitiga makna. Teknik pengumpulan data dengan mengamati iklan dan dianalisis khususnya profil, aktivititas atau peristiwa yang dianggap menunjukkan kesetaraan gender dengan menunjukkan citra laki-laki dalam keluarga. Penelitian ini berfokus pada audio, visual, dialog, background dan latar dalam iklan tersebut serta hasil analisis merupakan representasi kesetaraan gender yang ditinjau dari citra laki-laki dalam iklan Mama Lemon (Choky Sitohang), Supermie Ayam Bawang Jamur Yummy, Rapika Pelicin Pakaian, Sharp Sayang Listrik Super Aquamagic, Hilo (Ayah dan 
Anak), Belvita Breakfast, Pepsodent (Ayah Adi dan Dika), Susu SGM 3 (Pohon Strawberry), Ultra Milk Ultra Passion (Diajak ke Peternakan), Oreo (Hadirkan Keceriaan Masa Kecil), Soklin Lantai (Keluarga Bahagia Keluarga Soklin Lantai), Blue Band (Ibu Tahu yang Terbaik), SOS Pembersih Lantai (Bapak dan Anak), La Fonte Pasta (Ayah Memasak).

\section{HASIL PEMBAHASAN}

Empat puluh lima gambar yang terpilih dari beberapa iklan di bawah ini dianalisis menggunakan semiotika Charles Sanders Peirce. Analisis semiotika Peirce ini terdiri dari : 1) sign (tanda) merupakan representasi tanda verbal dan nonverbal termasuk simbol, warna, ekspresi, mimik muka, (Saussure menamakannya signifier atau penanda), 2) objek yaitu potongan gambar yang terpilih yang merujuk pada tanda. Objek ini mengacu pada citra laki-laki dalam keluarga. Objek dapat berupa representasi mental (ada dalam pikiran), dapat juga yang berupa sesuatu yang nyata diluar tanda, dan 3) interpretant yaitu bukan saja menafsirkan tanda, tetapi interpretasi mampu memberikan makna yang tersembunyi dari tanda tersebut. (Vera, 2014). Secara rinci analisis semiotika Charles Sanders Peirce empat puluh lima gambar dari iklan-iklan dapat diamati pada Tabel 1 berikut:

1. Iklan Belvita (Breakfast)

\section{Sign}

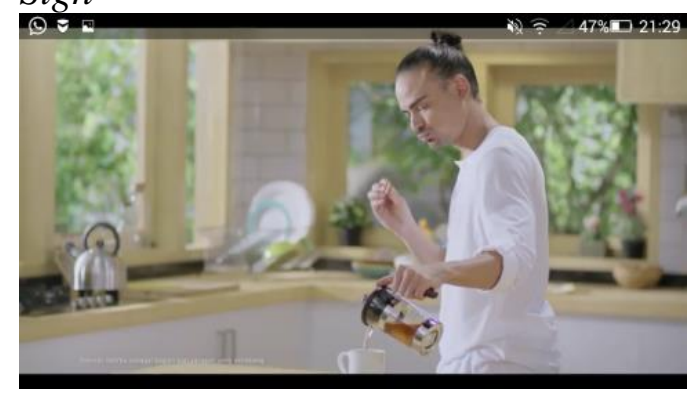

\section{Object}

Seorang laki-laki sedang menuang teh dan makan biskuit di dapur pada pagi hari

\section{Interpretant}

Laki-laki tersebut adalah seorang suami yang sedang menyiapkan sarapan sederhana berupa biskuit yang mampu mengenyangkan dan bergizi tanpa harus repot mencuci piring

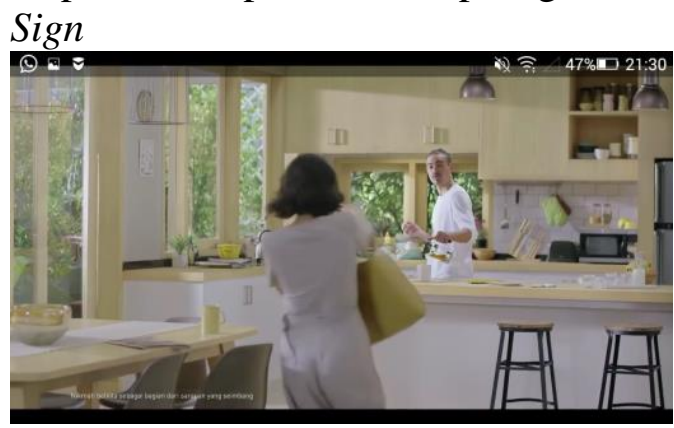

\section{Object}

Seorang suami dan isteri berada di dapur pada suasana pagi hari. Si suami menawarkan biskuit, si isteri membawa tas.

\section{Interpretant}

Seorang suami menawarkan biskuit yang bergizi untuk sarapan isterinya yang bersiap untuk berangkat kerja.

2. Iklan Ultra Milk Ultra Passion (Diajak ke Peternakan)

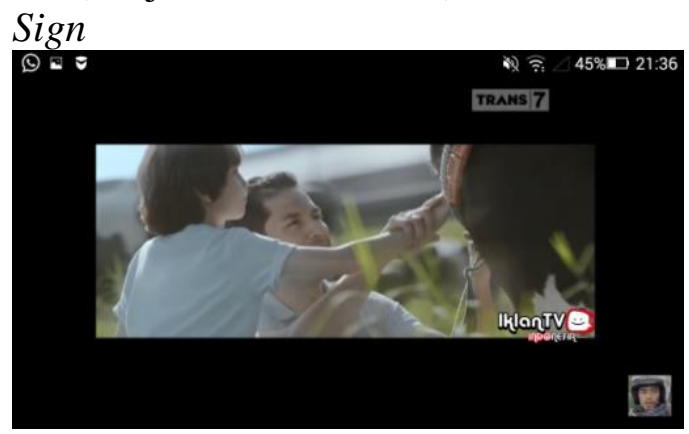

\section{Object}

Seorang ayah mengajak anaknya ke peternakan

\section{Interpretan}

Ayah memberi tahu sang anak bahwa kita harus merawat dan menyayangi hewan seperti orang tua menyayangi anaknya 


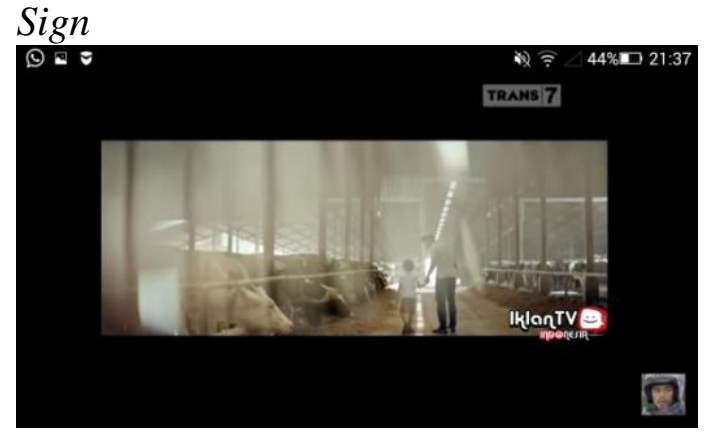

Object

Anak diajak masuk ke peternakan

\section{Interpretant}

Ayah menjelaskan jika sapi-sapi itu dirawat dengan kasih sayang maka akan menghasilkan susu yang banyak

Sign

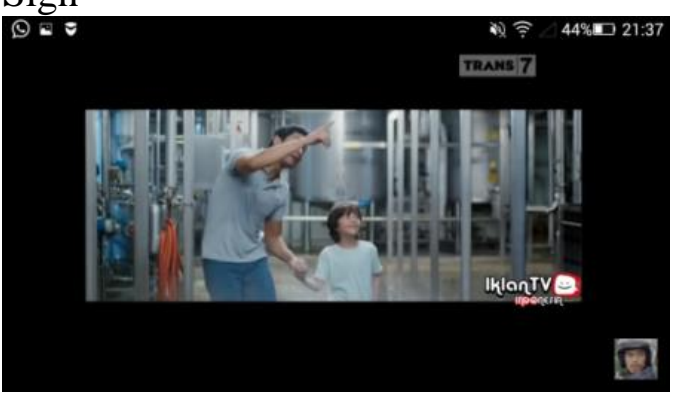

\section{Object}

Ayah membawa anak ke pabrik pengolahan susu

\section{Interpretant}

Sapi segar yang dihasilkan sapi langsung diolah dengan menggunakan teknologi canggih sehingga si anak tahu bagaimana proses pembuatan susu kesukaannya

3. Iklan Supermi Ayam Jamur Yummy

\section{Sign}

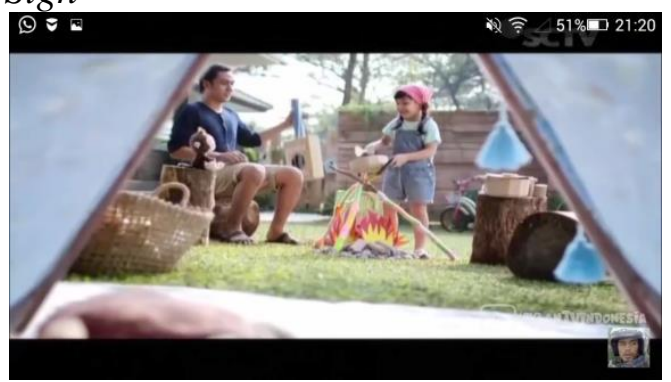

Object

Ayah menemani sang anak bermain Interpretant

Ayah bersama sang putri bermain kemah-kemahan di halaman rumah.
Sang anak menawarkan ingin memasakkan sesuatu untuk ayahnya

\section{Sign}

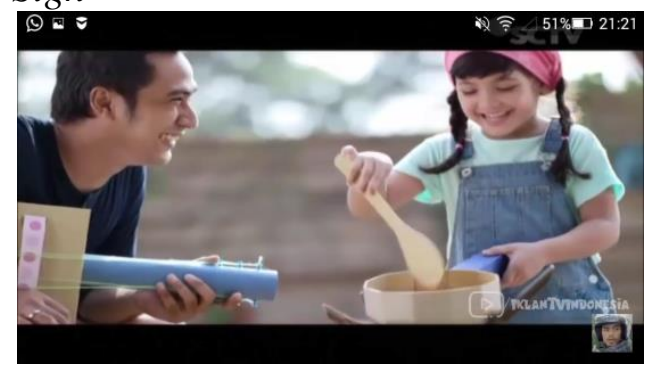

\section{Object}

Anak memasak (pretending)

\section{Interpretant}

Anak mulai bermain peran seperti ibunya, memasak sesuatu (kesukaan si anak makan Supermi), sedang sang ayah menemani sambil berdendang

4. Iklan Sos Pembersih Lantai Bapak Dan Anak

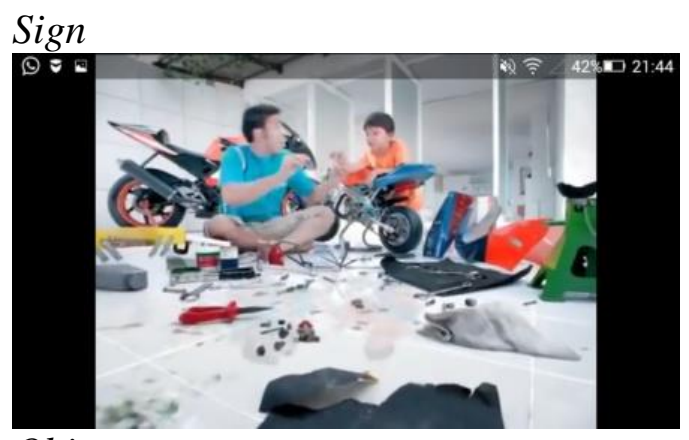

Object

Ayah dan anak merakit sesuatu, tampak lantai kotor terkena oli

Interpretant

Ayah dan anak sedang memperbaiki sepeda motor untuk anaknya

Sign

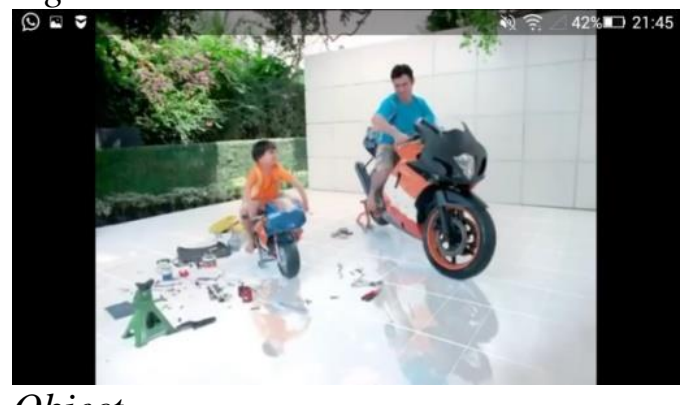

Object

Setelah selesai merakit, sepeda motor dinaiki 


\section{Interpretant}

Terlihat anak dan ayah memiliki hobi yang sama, yaitu sepeda motor besar

Sign

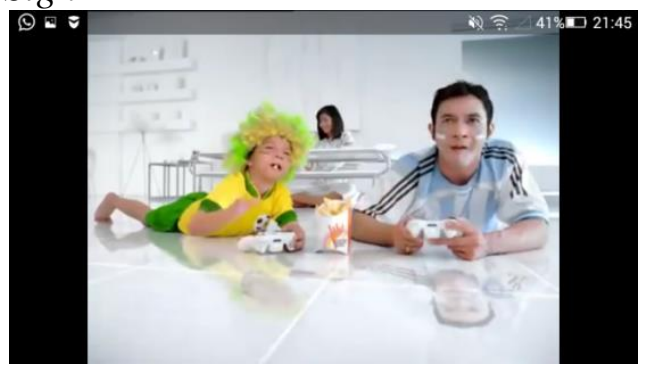

Object

Ayah dan anak sedang bermain game bersama

\section{Interpretant}

Bermain bersama di lantai dilakukan ayah dan anak ini. Lantai yang tadinya kotor, dengan SOS pembersih lantai, tidak ada masalah

Sign

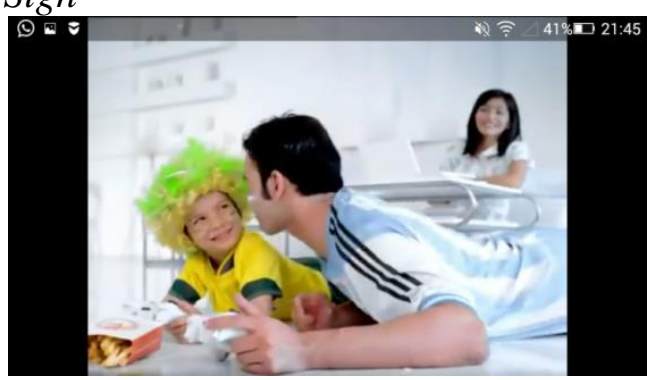

\section{Object}

Anak dan ayah bermain, ibu bekerja dengan tenang

Interpretant

Dengan lantai yang bebas kuman, sang ibu merasa tenang dan dapat bahagia dapat melakukan pekerjaannya

5. Iklan Soklin Pembersih Lantai (Keluarga Bahagia, Keluarga Soklin Lantai)

\section{Sign}

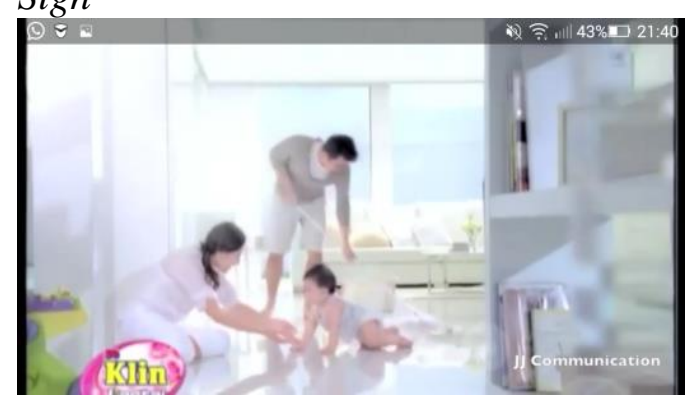

\section{Object}

Ayah sedang mengepel, ibu menemani anak

\section{Interpretant}

Keluarga ini memilih Soklin Pembersih Lantai sejak anak mereka masih merangkak (banyak aktivitas dilakukan di lantai)

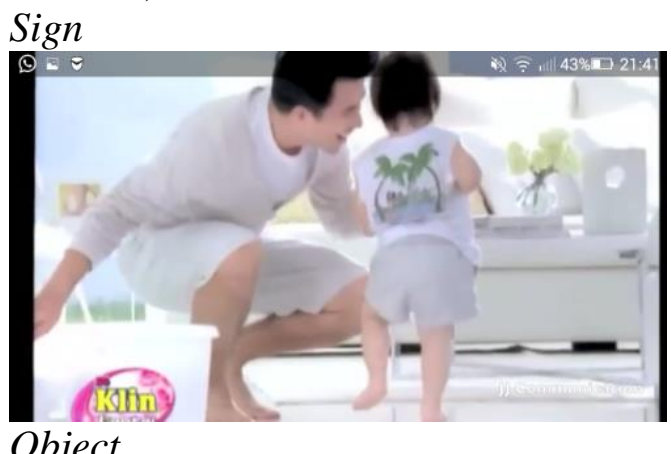

Ayah bermain dengan anak

\section{Interpretant}

Ketika sang anak mulai belajar berjalan pun, mereka tetap setia menggunakan produk ini

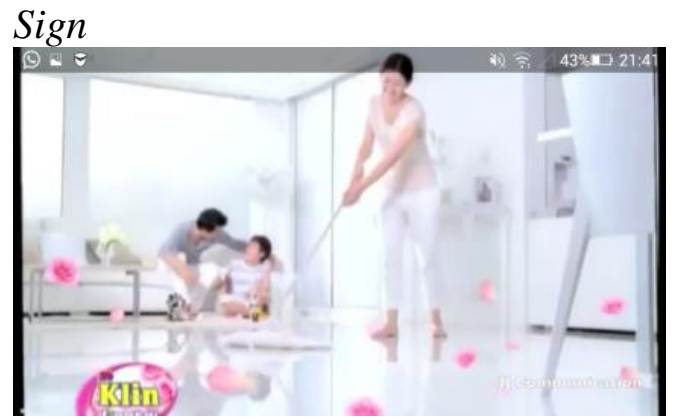

\section{Object}

Anak bermain dengan anak, ibu membersihkan lantai

\section{Interpretant}

Anak mulai tumbuh besar, namun keluarga ini tetap setia menggunakan produk pembersih lantai Soklin

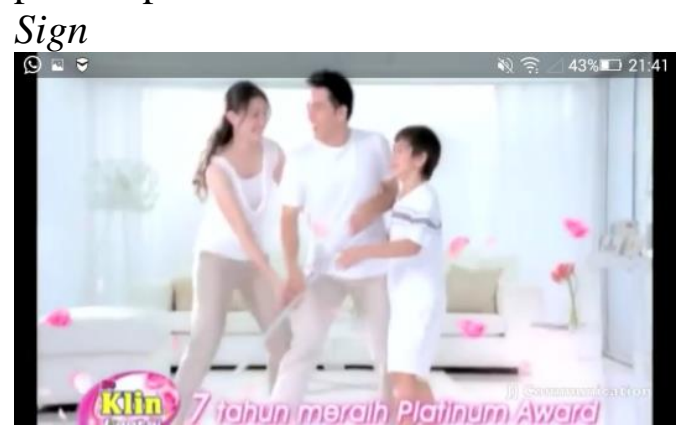


Object

Kebersamaan membersihkan rumah

\section{Interpretant}

Digambarkan ketika si anak tadi sudah mulai besar, orang tua mengajaknya membantu membersihkan rumah (mengepel) dengan produk yang sama. Keluarga ini terlihat kompak dan bahagia

6. Iklan Sharp Mesin Cuci Sayang Listrik

\section{Sign}

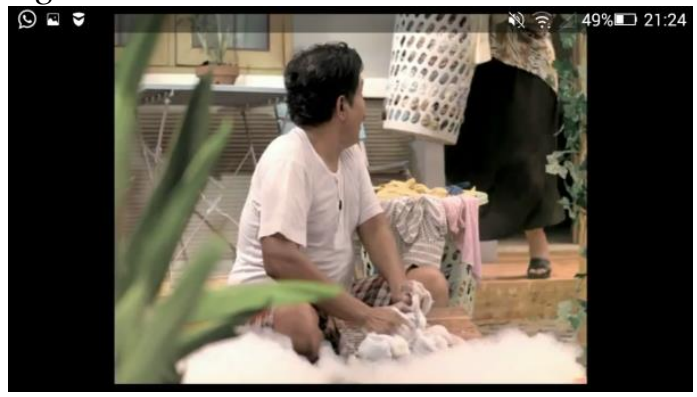

\section{Object}

Suami sedang mencuci baju

\section{Interpretant}

Suami sedang mencuci baju dengan tangan (mengucek), tujuannya agar disayang isteri. Padahal, sang suami ingin menghemat listrik

Sign

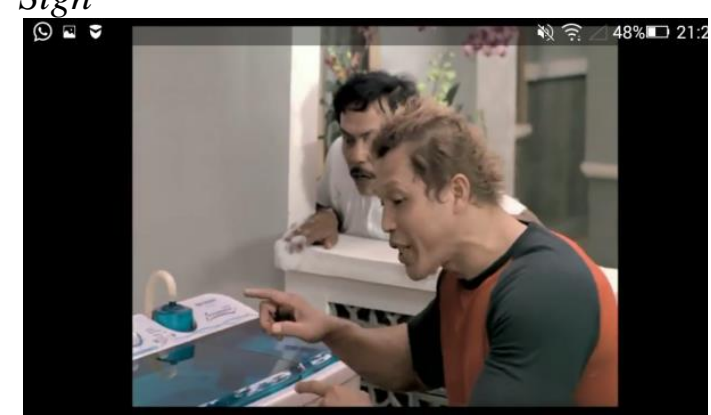

\section{Object}

Tetangganya memberi tahu produk mesin cuci yang hemat listrik

Interpretant

Tetangga sebelah yang melihat sang suami memberi tahu kalau ia menggunakan mesin cuci Sharp yang listriknya ringan (199 watt)

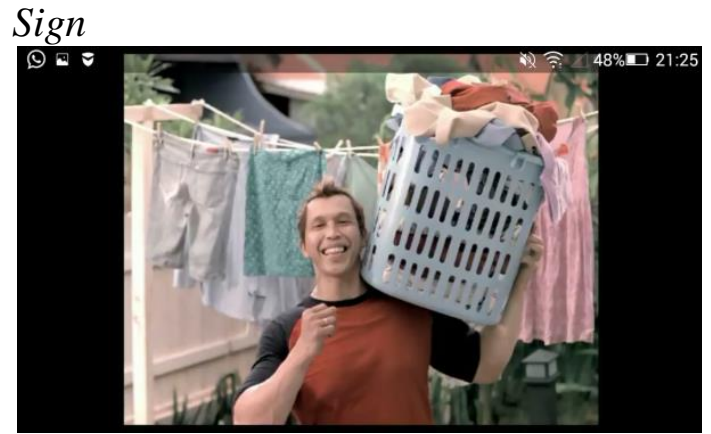

\section{Object}

Tetangga membawa hasil cuciannya yang sudah kering

\section{Interpretant}

Sang tetangga memperlihatkan hasil cuciannya yang banyak tanpa harus mengucek

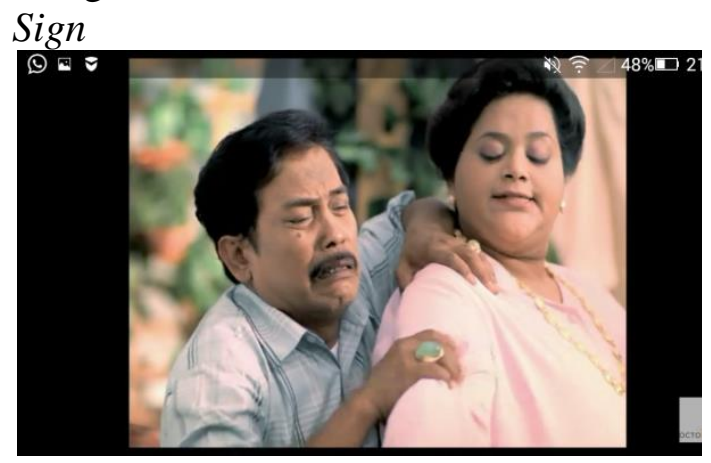

Object

Suami memijat isterinya

Interpretant

Akhirnya sang suami pun menggunakan mesin cuci yang sama, namun sang isteri malah minta suami memijatnya sebagai ganti mengucek baju

7. Iklan SGM 3 Versi Pohon Strawbery

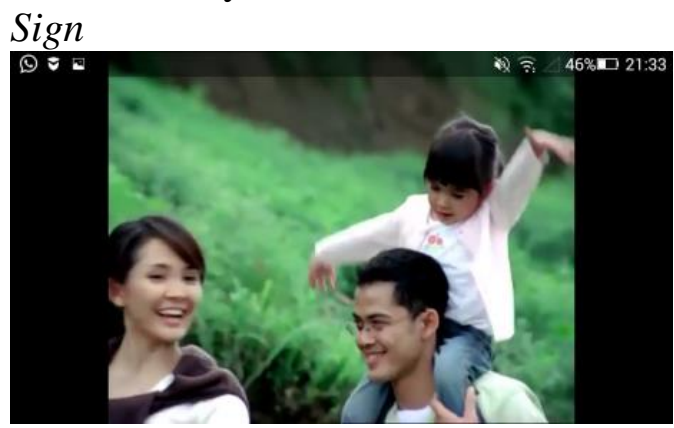

Object

Anak-anak bersama orang tuanya sedang jalan-jalan di perkebunan 


\section{Interpretant}

Sang anak dengan digendong sang ayah berjalan-jalan bersama temantemannya. Sang anak bernyayi "Naiknaik ke puncak gunung"

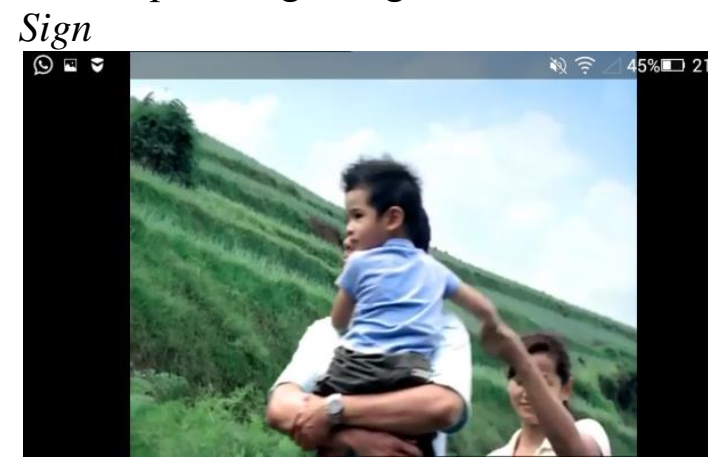

\section{Object}

Temannya (laki-laki) juga ikut berjalan-jalan

Interpretant

Ayah temannya juga mengggendong, namun tidak ada ekspresi

Sign

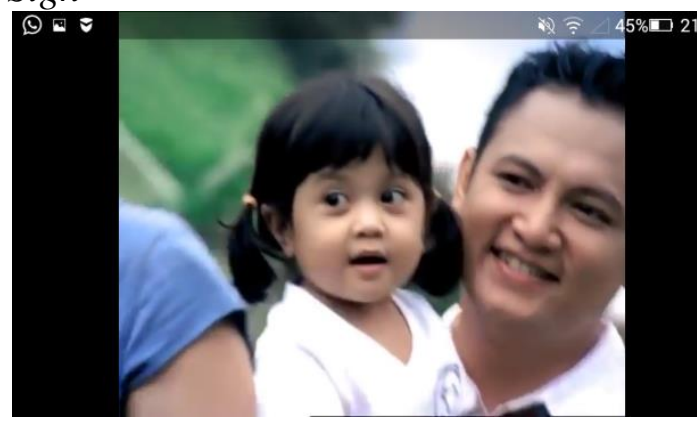

Object

Temannya yang lain juga digendong ayahnya

\section{Interpretant}

Saat sang anak menyanyi, lirik "pohon cemara" diganti "pohon strawberry" sehingga temannya tersenyum

Sign

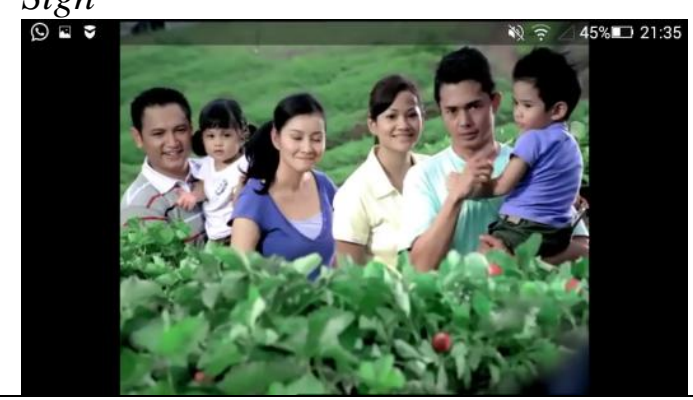

\section{Object}

Mereka sudah sampai di tengah perkebunan strawbery

Interpretant

Saat sampai di tengah perkebunan, mereka semua tertawa mendengar si anak yang kreatif mengganti lirik lagu sesuai suasana sekitar. Ayah dan ibunya amat bangga karena mereka selalu memberi sang anak susu SGM 3 8. Iklan Rapika

\section{Sign}

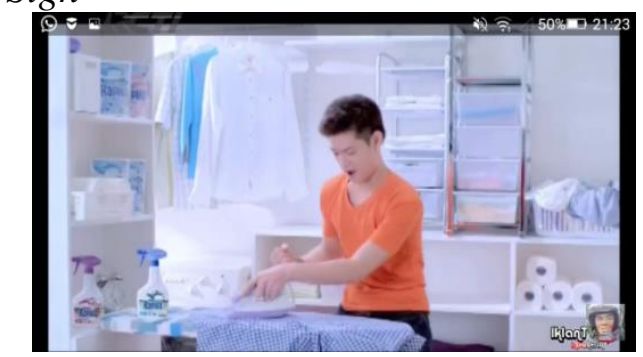

Object

Seorang anak laki-laki sedang menyetrika bajunya

\section{Interpretant}

Anak laki-laki tersebut terlihat sangat menikmati pekerjaannya karena menggunakan Rapika sebagai pelicin pakaian sehingga menyetrika menjadi pekerjaan yang menyenangkan

Sign

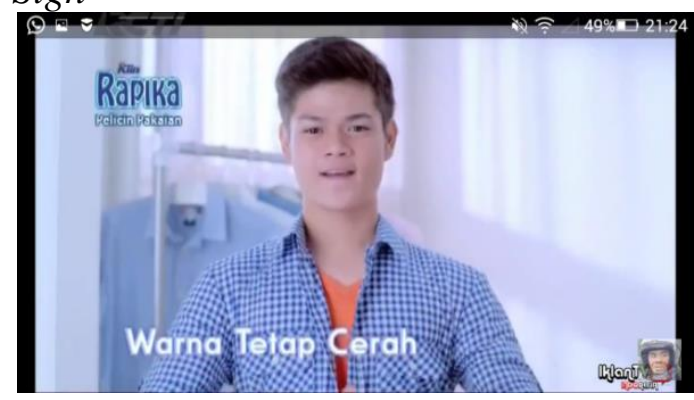

\section{Object}

Anak laki-laki menggunakan kemeja hasil setrikannya

\section{Interpretant}

Anak laki-laki tersebut mengenakan kemejanya yang sudah halus dan wangi. Dia juga bangga karena bisa mengerjakan sendiri 
9. Iklan Pepsodent (Versi Ayah Dan Dika)

\section{Sign}

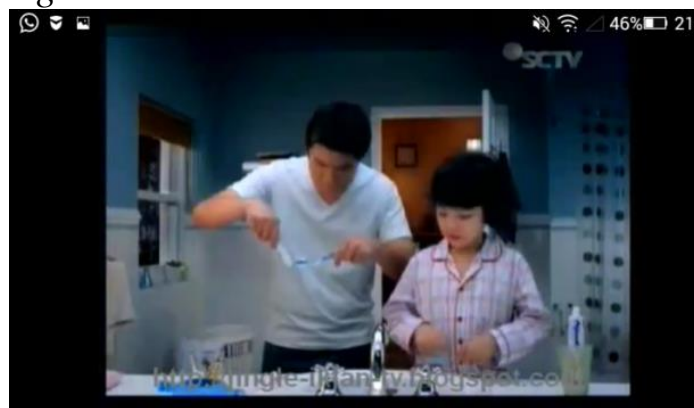

Object

Ayah Dika sedang bersiap menyikat gigi sebelum tidur

Interpretant

Ayah mengajak Dika menyikat giginya sebelum tidur dan member tahu bahwa jika menyikat gigi terburu-buru masih ada sisa-sisa makanan menempel

Sign

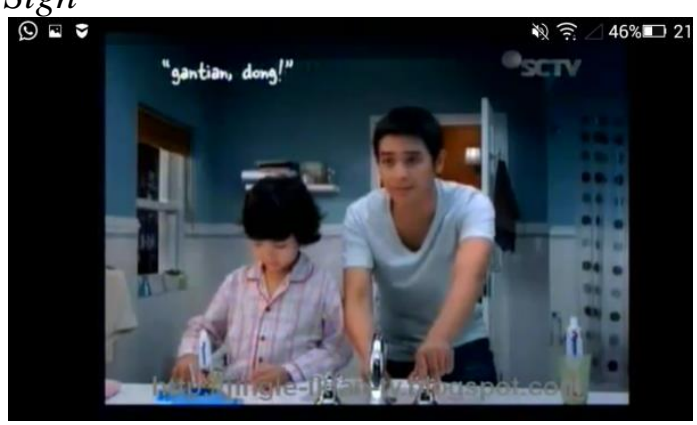

Object

Dika bersiap menyikat gigi sebelum tidur

\section{Interpretant}

Ayah Dika membantu Dika menyikat gigi dengan menunggunya sampai selesai

10. Iklan Oreo (Hadirkan Keceriaan Masa Kecil)

Sign

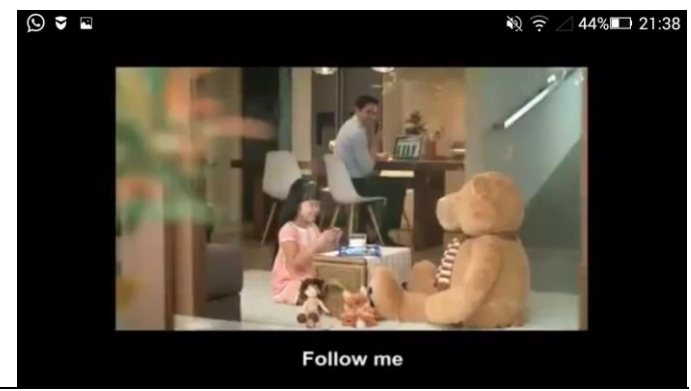

\section{Object}

Ayah melihat anaknya sedang bermain dengan boneka beruang

\section{Interpretant}

Ayah yang sedang menelepon menjadi tidak fokus karena sang anak sedang bercerita tentang kebiasaannya dengan teman-teman makan Oreo kepada boneka beruangnya

\section{Sign}

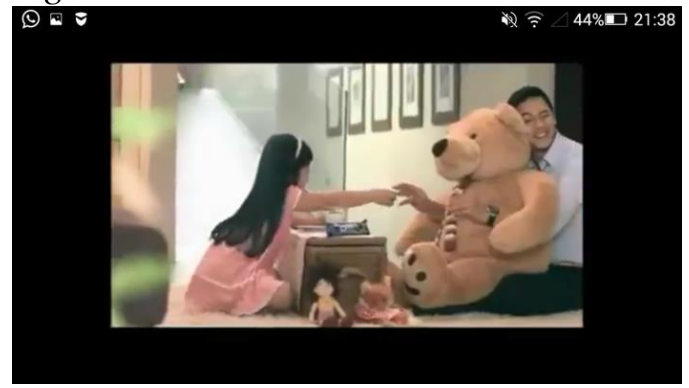

Object

Ayah menjadi boneka beruang

Interpretant

Ayah berpura-pura menjadi boneka beruang dengan bersuara dan bertingkah seperti teman anaknya

Sign

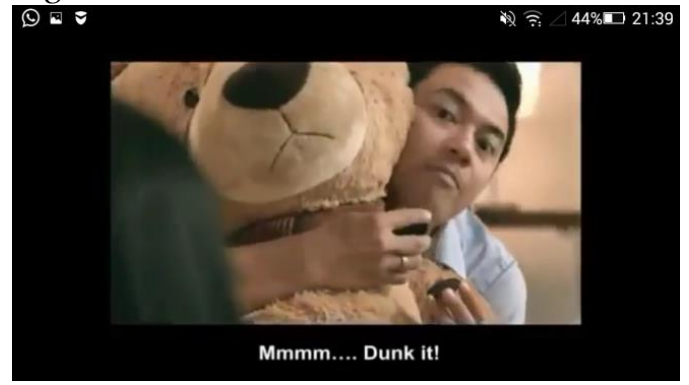

Object

Ayah mengambil biskuit Oreo

Interpretant

Ayah mengambil biskuit dan disuruh anaknya untuk mencelupkannya ke dalam susu

Sign

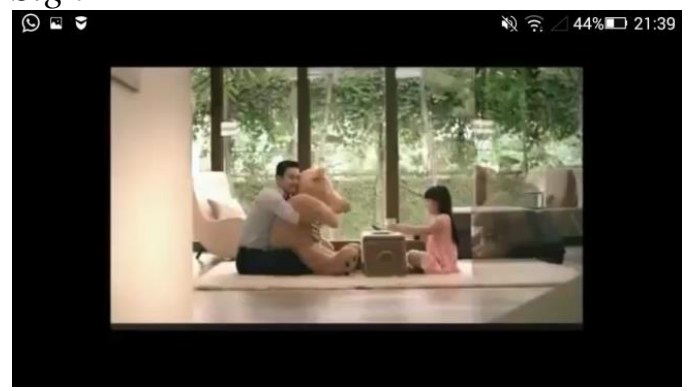


Object

Mereka bermain bersama

\section{Interpretant}

Ayah menikmati perannya sebagai boneka beruang sekaligus sebagai teman anaknya

Sign

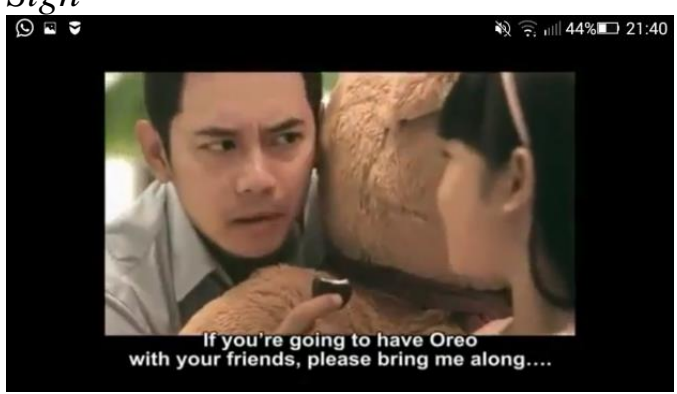

Object

Ayah minta diajak ikut bermain lain kali

\section{Interpretant}

Karena keseruannya, sang ayah akhirnya mengeluarkan pernyataan bahwa lain kali jika sang anak bermain bersama teman-temannya, ayah minta diikutsertakan. Ayah ingin merasakan indahnya masa anak-anak

11. Iklan Mama Lemon

Sign

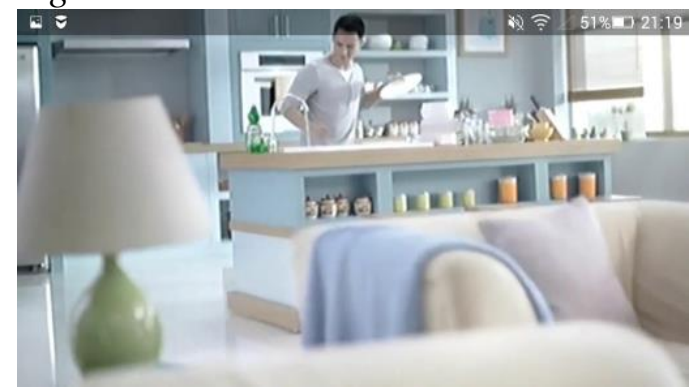

Object

Seorang laki-laki (diperankan oleh Choky Sitohang) sedang mencuci piring

Interpretant

Mencuci piring memang pekerjaan ibu atau wanita, namun digambarkan mencuci piring dapat menjadi pekerjaan mudah dengan menggunakan sabun pencuci piring Mama lemon

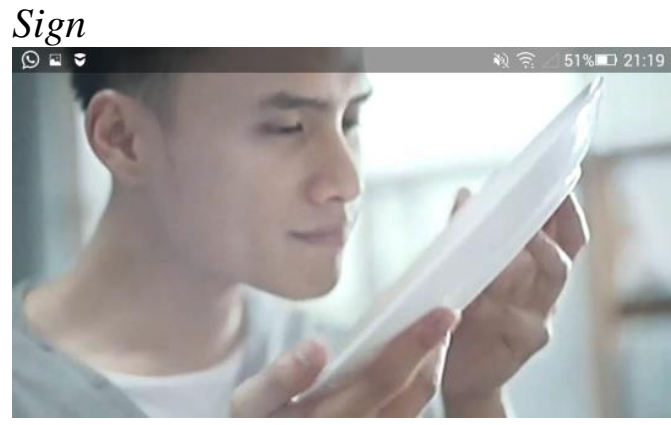

\section{Object}

Choky mencium hasil cucian piringnya Interpretant

Untuk membuktikan hasil cuciannya wangi dan tidak amis, Choky mencium piring yang tadi dicucinya

\section{Sign}

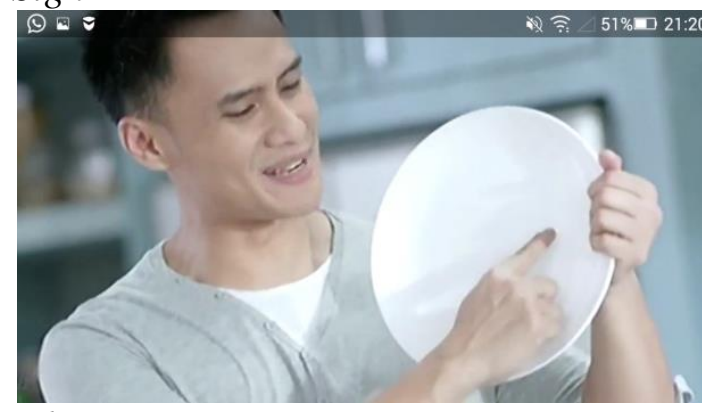

\section{Object}

Choky menggosok piringnya

\section{Interpretant}

Untuk membuktikan hasil cucian piringnya kesat, Choky menggosokkan tangannya di atas piring yang baru dicucinya

$$
\begin{aligned}
& \text { 12. Iklan Lafonte (Versi Ayah } \\
& \text { Memasak) }
\end{aligned}
$$

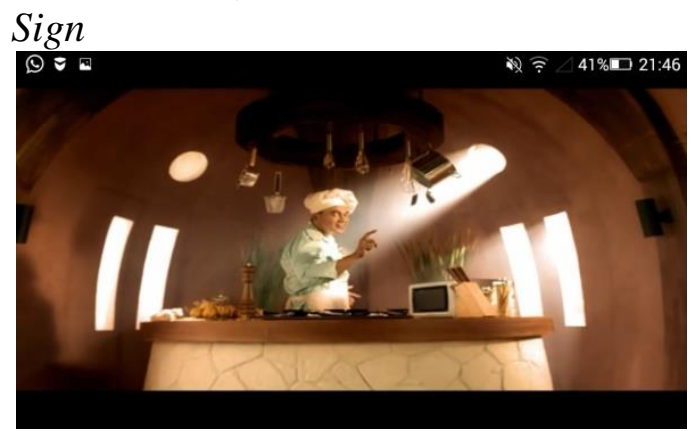

Object

Ayah menggunakan baju koki siap memasak

\section{Interpretant}

Seorang ayah yang akan memasak untuk isteri dan kedua anaknya 


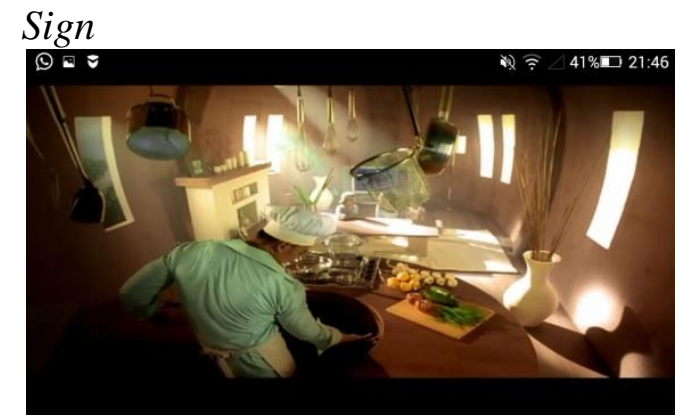

Object

Ayah mulai memasak

\section{Interpretant}

Ayah memilih memasak dari bahan sehat dan bergizi, dengan waktu 30 menit yaitu spageti Lafonte yang dibuat dari gandum pilihan dan bahan-bahan tambahan bergizi lainnya

Sign

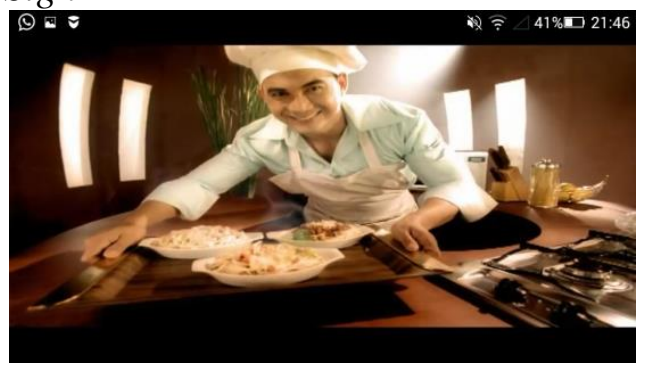

Object

Sang koki ayah sudah selesai memasak Interpretant

Ayah sudah selesai memasak tiga porsi spageti bolognise lalu dicicipi oleh anak-anak dan isterinya. Komentar mereka adalah aldente

13. Iklan Hilo (Ayah \& Anak)

Sign

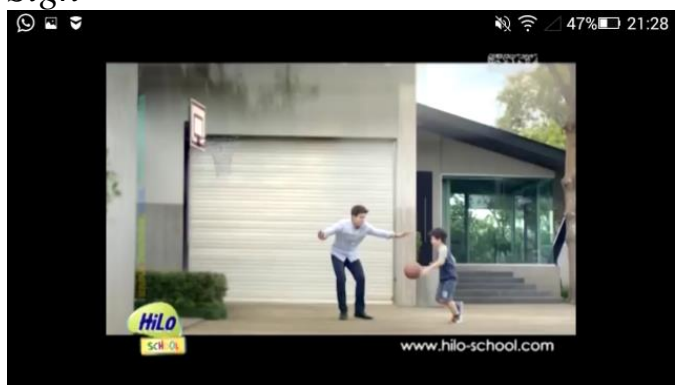

Object

Ayah dan anak bermain basket

Interpretant

Ayah yang baru pulang kantor diajak main basket bersama anak lelakinya

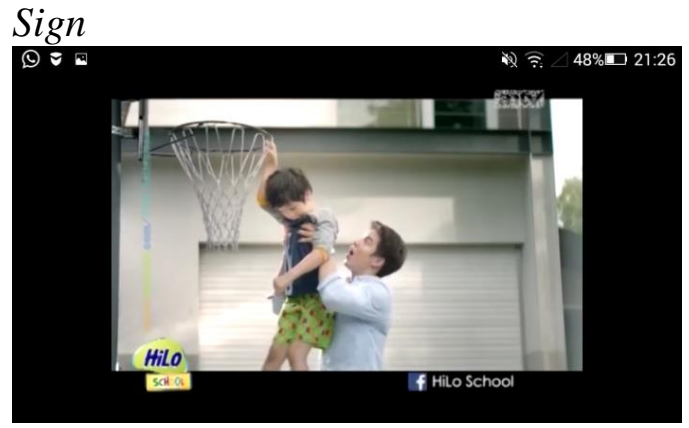

\section{Object}

Ayah menggendong sang anak agar dapat memasukkan bola ke dalam ring Interpretant

Ketika sang ayah menggendong anaknya agar dapat memasukkan bola ke dalam ring (seperti sang ayah), namun ternyata celana anak melorot. Sang anak ingin seperti idolanya (sang ayah) yang tinggi

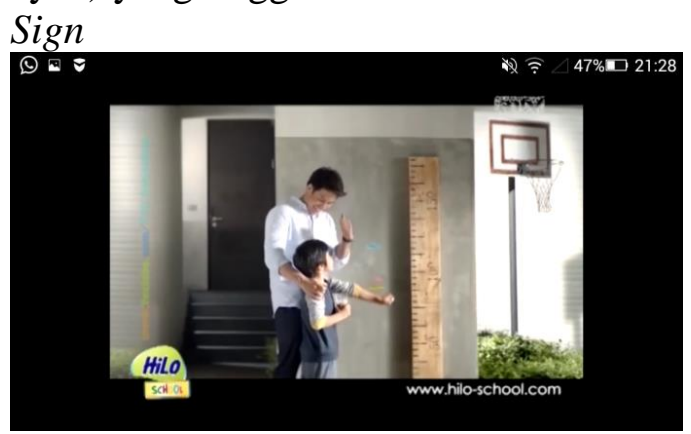

\section{Object}

Ayah mengajak anak mengukur tinggi badan

\section{Interpretant}

Ayah menjelaskan bahwa agar menjadi tinggi harus minum susu pertumbuhan Hilo (tumbuh itu ke atas, bukan ke samping)

14. Iklan Blue Band (Ibu Tahu Yang Terbaik)

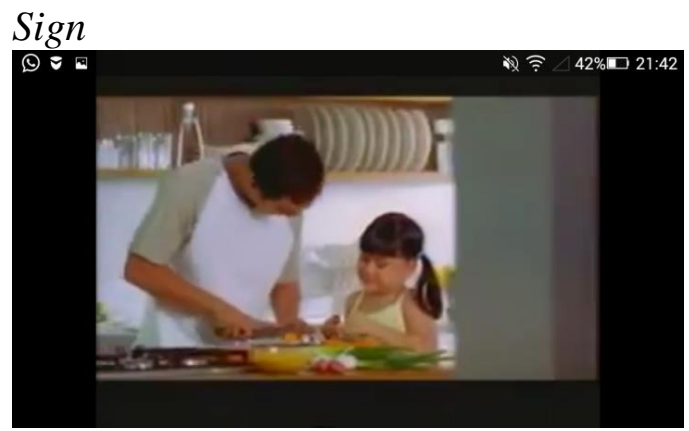


Object

Ayah memasak untuk anaknya Interpretant

Ayah memasak untuk anak perempuannya karena ibunya sedang tidak ada di rumah.

Sign

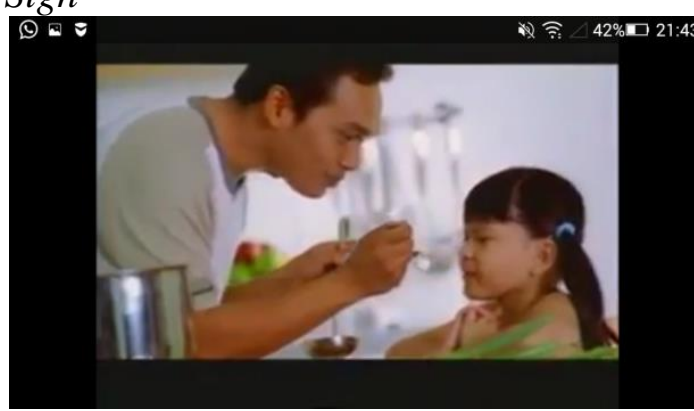

Object

Ayah meminta anaknya mencicipi masakannya

Interpretant

Ketika ayah meminta anaknya mencicipi masakannya, sang anak mengatakan masih belum sama seperti masakan mamanya

Sign

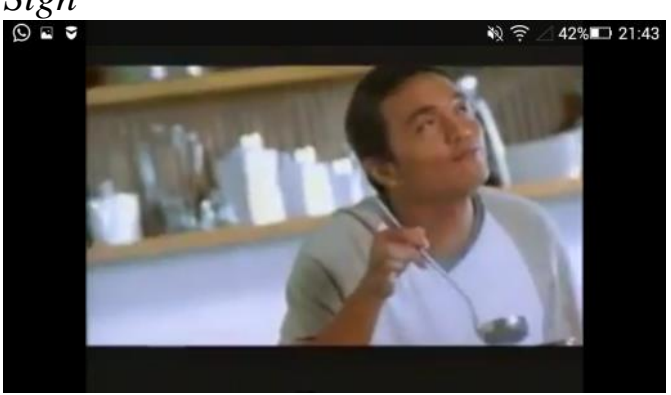

Object

Ayah mencicipi kembali masakannya setelah menemukan resep rahasia isterinya

Interpretant

Setelah ayah menelepon isterinya, ternyata resepnya adalah dengan menambahkan blueband sehingga rasa masakan menjadi lebih enak
Sign

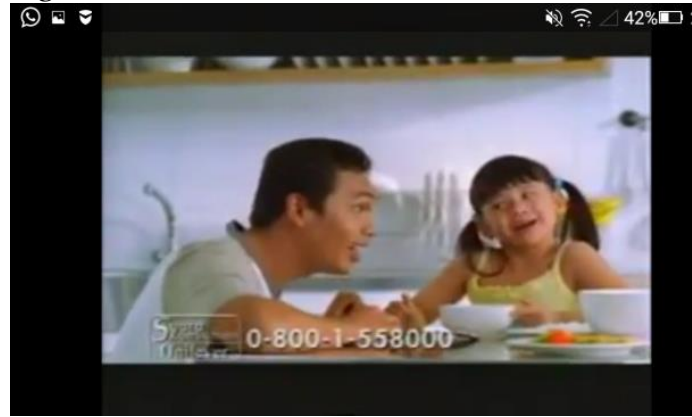

Object

Anak dan ayah makan bersama

Interpretant

Setelah masakan matang dan rasanya seenak masakan mama, mereka makan bersama

\section{Penafsiran Temuan Penelitian}

Citra adalah suatu kesan atau persepsi yang ditujukan pada seseorang, kelompok, atau masyarakat. Citra bisa dikonstruksi dan dipersepsi oleh seseorang seperti yang diinginkan. Konten iklan ini mengenai kehidupan laki-laki dan perannya dalam menjalankan keluarga. Segala kegiatan laki-laki dalam keluarga menjadi sebuah representasi kesetaraan gender yang ditinjau dari citra laki-laki dalam keluarga. Hal tersebut akan diuraikan dalam subbab ini.

Iklan nomor 1, 5, 6, 8, 11, 12, 14, menggambarkan pekerjaan rumah tangga yang dilakukan oleh peran laki-laki sebagai ayah, suami, dan anak. Pekerjaan dalam rumah tangga yang dimaksud di antaranya menyiapkan sarapan sederhana berupa biskuit yang mampu mengenyangkan dan bergizi tanpa harus repot mencuci piring yang digambarkan pada iklan nomor 1 . Kemudian kegiatan mengepel lantai yang digambarkan pada iklan nomor 5 dilakukan seorang ayah sejak anak mereka mulai bisa merangkak. Pada iklan nomor 6 menunjukkan seorang suami yang sedang mencuci baju secara tradisional menggunakan tangan kemudian tetangga mereka datang menunjukkan cara mencuci dengan cara yang hemat dan praktis menggunakan 
mesin cuci, dan hasilnya bisa ditunjukkan dengan gambaran laki-laki yang mengangkat baju kering dari jemuran dengan cepat tanpa harus menunggu lama. Pada iklan nomor 8, seorang anak berusia remaja melakukan kegiatan rumah tangga berupa menyetrika. Produk yang ditawarkan membuat anak remaja laki-laki bisa menyetrika dengan mudah dan membuat baju menjadi rapi. Iklan berikutnya adalah nomor 11 menggambarkan seorang laki-laki yang mencuci piring dengan mudah tanpa repot dengan menggunakan produk sabun pencuci piring tersebut. Iklan terakhir yang menggambarkan seorang laki-laki yang berperan sebagai ayah melakukan kegiatan memasak ditunjukkan pada iklan nomor 12, dan 14.

Pada iklan nomor 2, 4, 5, 7, 9, 14, menunjukkan kegiatan laki-laki yang berperan sebagai ayah dalam sebuah keluarga yang melakukan kegiatan bersama dengan anak dan keluarganya. Pada iklan nomor 2, seorang ayah mengajak anaknya mengunjungi sebuah peternakan dengan menunjukkan gambaran kebersamaan ayah dan anak di dalam mobil dalam perjalanan menuju peternakan, kemudian sang ayah memperkenalkan binatang-binatang yang mampu memproduksi susu. Setelah itu anak diajak berkeliling untuk melihat kinerja mesin berteknologi canggih yang mampu mengolah susu sapi menjadi layak minum. Pada iklan nomor 4, kebersamaan yang ditunjukkan dalam iklan adalah melakukan pekerjaan mekanik. Ayah dan anak membongkar sepeda motor dan memperbaikinya bersama. Iklan berikutnya adalah iklan nomor 5 yang menggambarkan ayah, ibu, dan anak yang beranjak remaja melakukan pekerjaan mengepel lantai bersama. Iklan nomor 7 menggambarkan kegiatan keluarga bersama-sama bertamasya dan berjalan-jalan ke perkebunan. Tampak pada potongan gambar, anak-anak digendong oleh ayah-ayah mereka berkeliling perkebunan. Berikutnya pada iklan nomor 9 menggambarkan kegiatan anak dan ayah bersama-sama menggosok gigi. Kearaban digambarkan dengan jelas dalam potongan gambar iklan tersebut. Iklan terakhir dalam kategori ini menggambarkan kegiatan memasak bersama yang dilakukan seorang ayah dan anak perempuannya. Sang anak perempuan menjadi foodtester untuk makanan yang dibuat ayahnya.

Pada iklan nomor 3, 4, 5, 10, 13, menggambarkan kegiatan seorang ayah yang menemani dan bermain bersama anaknya. Pada iklan nomor 3 digambarkan seorang Ayah bersama anak perempuannya bermain kemah-kemahan di halaman rumah. Sang anak menawarkan ingin memasakkan sesuatu untuk ayahnya. Iklan berikutnya yaitu nomor 4, bermain bersama di lantai dilakukan ayah dan anak. Pada iklan tersebut digambarkan kenyamanan ayah dan anak bermain bersama di lantai yang bersih, dan sang ibu merasa bahagia karena melihat ayah dan anak juga bahagia. Berikutnya iklan nomor 5 menggambarkan ayah dan anak yang nyaman juga bermain bersama di lantai yang bersih berkat produk pembersih lantai yang mereka gunakan. Iklan nomor 10 , menunjukkan seorang ayah yang akhirnya menemani anaknya bermain dengan boneka. Sang ayah berpura-pura menyuarakan boneka beruang yang sedang diajak main anaknya. Dan keakraban ayah dan anak ini semakin terjalin. Iklan selanjutnya adalah iklan nomor 13, seorang ayah pulang bekerja masih mengenakan seragam kerjanya melihat anaknya bermain basket, dan akhirnya ayahnya pun menemani dan bermain basket bersama.

Terakhir pada iklan nomor 6, peran suami yang menggambarkan kegiatan memijat isteri. Hal tersebut dilakukan karena waktu yang luang 
menjadi banyak karena sang suami tidak lagi mencuci baju menggunakan tangan, tetapi menggunakan mesin cuci.

\section{SIMPULAN}

Berdasarkan hasil analisis model semiotika Charles Sanders Pierce terhadap penelitian representasi kesetaraan gender yang ditinjau dari citra laki-laki dalam keluarga pada iklan televisi, dapat ditarik simpulan bahwa, melalui penggambaran iklan di televisi, laki-laki mampu melakukan pekerjaan atau kegiatan yang biasanya dilakukan seorang perempuan dalam rumah tangga. Dari 14 iklan diperoleh 45 potongan gambar yang menunjukkan kegiatan tersebut. Persentase kegiatan rumah tangga yang dilakukan oleh laki-laki dalam iklan-iklan tersebut yaitu bermain bersama anak sebanyak $26,6 \%$, melakukan kegiatan bersama anak dan keluarga sebanyak $35,5 \%$, melakukan pekerjaan rumah tangga (mengepel lantai, mencuci baju, mengoperasikan mesin cuci, mengangkat baju kering yang dijemur, menyetrika, mencuci piring, memasak, menyiapkan sarapan) sebanyak 33,3\%, dan memijat isteri sebanyak $2,22 \%$. Jadi, dapat dikatakan bahwa lelaki pun dapat mengerjakan pekerjaan rumah tangga seperti mengepel lantai, mencuci baju, mengoperasikan mesin cuci, mengangkat baju kering yang dijemur, menyetrika, mencuci piring, memasak, menyiapkan sarapan seperti yang dimunculkan dalam iklan-iklan televisi tanpa mengubah citra yang dimiliki laki-laki.

\section{Ucapan Terima Kasih}

Penulis mengucapkan terima kasih kepada berbagai pihak yang telah membantu dalam proses penelitian ini.

\section{DAFTAR PUSTAKA}

Abdullah, I. (ed.). (2003). Sangkaan Peran Gender. Yogyakarta: Pustaka Pelajar

Assael, H. (2002). Consumer Behavior and Marketing Action. Fourth Edition. Boston: PWS-Kent Publishing Company.

Bhasin, K. (2001). Memahami Gender. Jakarta: Teplok Press

Fahmi, A. A. (1997). Bersama Televisi Merenda Wajah Bangsa. Jakarta: YPKMD

Jefkins, F. (1997). Periklanan. Jakarta: Erlangga.

Kasali, R. (2005). Manajemen Public Relations: Konsep dan Aplikasinya di Indonesia. Jakarta: Penerbit Grafiti.

Kurniawan. (2009). Tesis: Gender dan Patriarki dalam Antologi sihir perempuan karya Intan Paramadhita. Depok: UI Press.

------. (2001). Semiologi Roland Barthes. Magelang: Yayasan Indonesiatera.

Noviani, R. (2002). Jalan Tengah Memahami Iklan. Yogyakarta: Pustaka Pelajar.

Rahmawati, A. (2004). "Persepsi Remaja tentang Konsep Maskulin dan Feminim Dilihat dari Beberapa Latar Belakangnya." Skripsi pada jurusan PPB UPI Bandung: tidak diterbitkan

Santrock. J. W. (2003). Adolescence: Perkembangan Remaja.(edisi keenam). Jakarta: Erlangga.

Sari, R. P. (2007). Women For PeacePerempuan untuk Perdamaian Indonesia. Jakarta: Filsafat UI Press. 
Sobur, A. (2001). Analisis Teks Media: Suatu Pengantar untuk Analisis Wacana, Analisis Semiotik, dan Analisis Framing. Bandung : PT Remaja Rosda Karya.

------. (2012). Analisis Teks Media. Bandung: PT Remaja Rosda Karya.

Yulianita, N. (2005). Dasar-Dasar Public Relations. Bandung:
Fakultas Ilmu Komunikasi Universitas Islam Bandung.

http://www.bengkelappek.org/opini/174kesetaraan-gender-peran-antaralaki-laki-dan-perempuan-yangseimbang.html

http://acppost.blogspot.co.id/2016/08/citr a-laki-laki-dalam-iklan.html 